\title{
PARK VISITORS VS BEACH TOURISTS A COMPARATIVE STUDY IN AN ITALIAN COASTAL REGION
}

\author{
Salvatore Bimonte ${ }^{\mathrm{a}^{*}}$ \\ ${ }^{a}$ University of Siena, Department of Political Economy, Piazza S. Francesco 7, 53100 \\ Siena, Italy, tel: + 390577 235053, fax: + 390577 232661, e-mail: bimonte@unisi.it \\ * Corresponding author
}

\begin{abstract}
This study investigates and discusses the controversial question of whether naturebased tourists (NBTs) are more sensitive to socio-cultural and environmental resources, have different attitudes toward local products and more positive economic effects on host communities and destinations than beach tourists (BTs). In order to test these aspects, a simultaneous comparative analysis of these two types of tourist based on an a priori and activity-based segmentation was carried out. Data was collected by questionnaire at two sites in the Maremma (a costal area in southern Tuscany, Italy), each specific to the type of tourist investigated. In line with the findings of other studies, the results confirm that NBTs are older, more educated, more affluent, and more often employed in professional occupations than BTs. They also confirm the hypothesis that NBTs are more sensitive to environmental quality and have a more positive socio-economic impact. This study likewise highlights the strong role played by psychographic information in explaining tourist behavior. Three innovative findings concerning the relationship between income, education, personal commitment to the environment and tourist type are discussed at the end.
\end{abstract}

Keywords: nature-based tourist, comparative study, environmental concern, economic impact, willingness to pay.

\section{Introduction}

The many problems triggered by "mass" tourism have led to a call for “alternative” tourism (Brohman, 1996; Weaver, 1991; Butler, 1990; Dernoi, 1981), broadly defined as "forms of tourism that are consistent with natural, social and community values and which allow both hosts and guests to enjoy a positive and worthwhile interaction and shared experiences" (Smith and Eadington, 1995, p. 3) ${ }^{1}$. One of the most debated and investigated forms of alternative tourism is nature-based tourism $^{2}$, which represents a significant and rapidly growing share of the tourist industry (Mehmetoglu, 2005; Nyaupane et al., 2004; IES, 2000; Lindberg, 1998). The WTO estimates that it generates approximately $20 \%$ of all international travel expenditures (Newsome et al., 2002) ${ }^{3}$. This figure, together with the different attitudes 
and behavioral patterns that are assumed to characterize tourists who practice this type of tourism, justifies the attention that policy makers have recently been devoting to this segment of the tourist market.

Echoing the principles that define them, the nature-based tourists (NBTs) are supposed to have less negative socio-cultural and environmental impact on host communities, and to bring greater benefits to the economy of destinations (Epler Wood, 2002, Wallace and Pierce, 1996; Silverberg et al., 1996; Smith and Eadington 1995; Butler 1990; Ceballos-Lascurain, 1988) than other types of tourist (Jafari, 1990; Wight, 1993; Wallace and Pierce 1996). According to the definition, nature-based tourists prefer small, family-run facilities, are more sensitive to natural and cultural resources, are more interested in local and "green" products and engender a greater multiplier effect (see Wurzinger and Johansson, 2006; Macleod, 2003; Blamey and Braithwaite, 1997; Wight, 1996b; Cazes, 1989).

In order to verify such issues, more empirical simultaneous comparative studies are required. Unfortunately, as noted by Xiao and Smith (2006), few studies on tourism have adopted a comparative approach and, according to Hvenegaard (2002), most use a data-driven approach (a posteriori segmentation) ${ }^{4}$ which gives rise to the problems highlighted by Weaver (2002). These aspects are even wider in studies on nature-based tourism.

Although there have been different types of segmentation studies on tourism (Bonn et al. 2005; McKercher, 2001; Kashyap and Bojanic, 2000; Baloglu and McCleary, 1999) and the association between types of alternative tourist and conservation motivations (Lou and Deng, 2008) and/or economic and social impacts (Aylward, and Lutz, 2003, Taylor et al., 2003, Wallace and Pierce, 1996; Lindberg et al., 1996) have been examined, to the author's knowledge no simultaneous comparative analysis based on an a priori segmentation has been documented so far in the literature on $\mathrm{NBT}^{5}$.

In an attempt to narrow this gap, the present research compared two types of tourists holidaying simultaneously in the same area: nature-based tourists (NBTs) and beach tourists (BTs). The main goal was to verify whether NBTs are more sensitive to environmental quality, have different attitudes toward local produce and more positive economic impacts on host communities and destinations than BTs ${ }^{6}$. It also investigated whether and to what extent tourists behavioral patterns depend on the type of tourist one belongs to (psychographic information), rather than on socioeconomic characteristics (enabling conditions à la Sen), as some economic theoretical models show (for example those on the Environmental Kuznets Curve, see Bimonte 2002; Magnani 2000).

This being the purpose of the research, the first step was to define the two types of tourist and choose a way of segmenting them. An a priori and activity-based segmentation method was selected to carry out the analysis. This appeared to be the most appropriate method because the starting point of the research was not the entire 
population of tourists or a specific segment to further split into data-driven groups according to a particular variable. The research aimed at exploring systematic differences between two particular subgroups of the population of tourists clearly defined by a specific vacation activity.

\section{Defining tourist type: background}

Alternative and mass tourism, including the type known as 3S (sea, sand and sun), have been considered mutually exclusive and depicted in dichotomous terms, with alternative tourism being considered the "good" and mass tourism the "bad" (Clarke, 1997; Mowforth \& Munt, 1998; Jafari, 2000). This view has recently been challenged and a new perspective proposed, which considers alternative and mass tourism as extremes of a continuum, with no clear-cut boundary between the two in terms of "good" and "bad" values (Weaver, 2005; Weaver, 2001; Acott et al., 1998). According to the two paradigms implied by these views, good is considered an inherent property of certain types of tourism or a characteristic that no existing form of tourism inherently possesses, but a goal to achieve.

The shift in attitudes to tourism and empirical evidence indicate that a clear-cut boundary between types of tourism is difficult to imagine, one reason being that many or even most tourists engaged in alternative activities are mass tourists (Weaver, 1999), and several forms of alternative tourism, such as nature-based tourism, overlap with other forms of tourism, including beach tourism (Weaver et al. 1998; Mehmetoglu, 2007). This makes it necessary to find a way of classifying tourists before beginning any kind of analysis.

Hvenegaard (2002) defines four main empirical ways of classifying tourists: researcher-based, respondent-based, motivation-based and activity-based. In the latter case the researcher defines the different varieties of tourist on the basis of places visited and activities engaged in.

According to the activity-based approach, tourists who travel to natural areas or destinations are considered NBTs (see Holden and Sparrowhawk, 2002, Lang and O'Leary, 1997). This does not mean that we should regard NBTs as a homogeneous group (Wight, 2001). Various methods have been proposed to differentiate them: for example, Laarman and Durst (1987) distinguished hard and soft NBTs, whereas Lindberg (1991) identified four types of NBT, i.e. hard-core, dedicated, mainstream and casual, the latter being those who partake of nature as part of a broader itinerary.

\section{Method and sample description}

\section{Definition of nature-based and beach tourists}

The present study compared two types of tourists: NBTs and BTs. It considered NBTs to be tourists who visited the Natural Park of the Maremma during their vacation (casual nature tourists), and BTs to be seaside resort tourists who passed their 
holiday in the area without visiting the park. Due to the characteristics of beach tourism in the Maremma, the latter may be considered representative of the mass tourist $^{7}$. These two types of tourist were chosen because both "consume" a natural resource, namely the park and the seaside, while sojourning simultaneously in the area. We could say that both are nature-oriented, but interact with the natural resource in quite different ways (Newsome et al., 2002; Weaver, 2001).

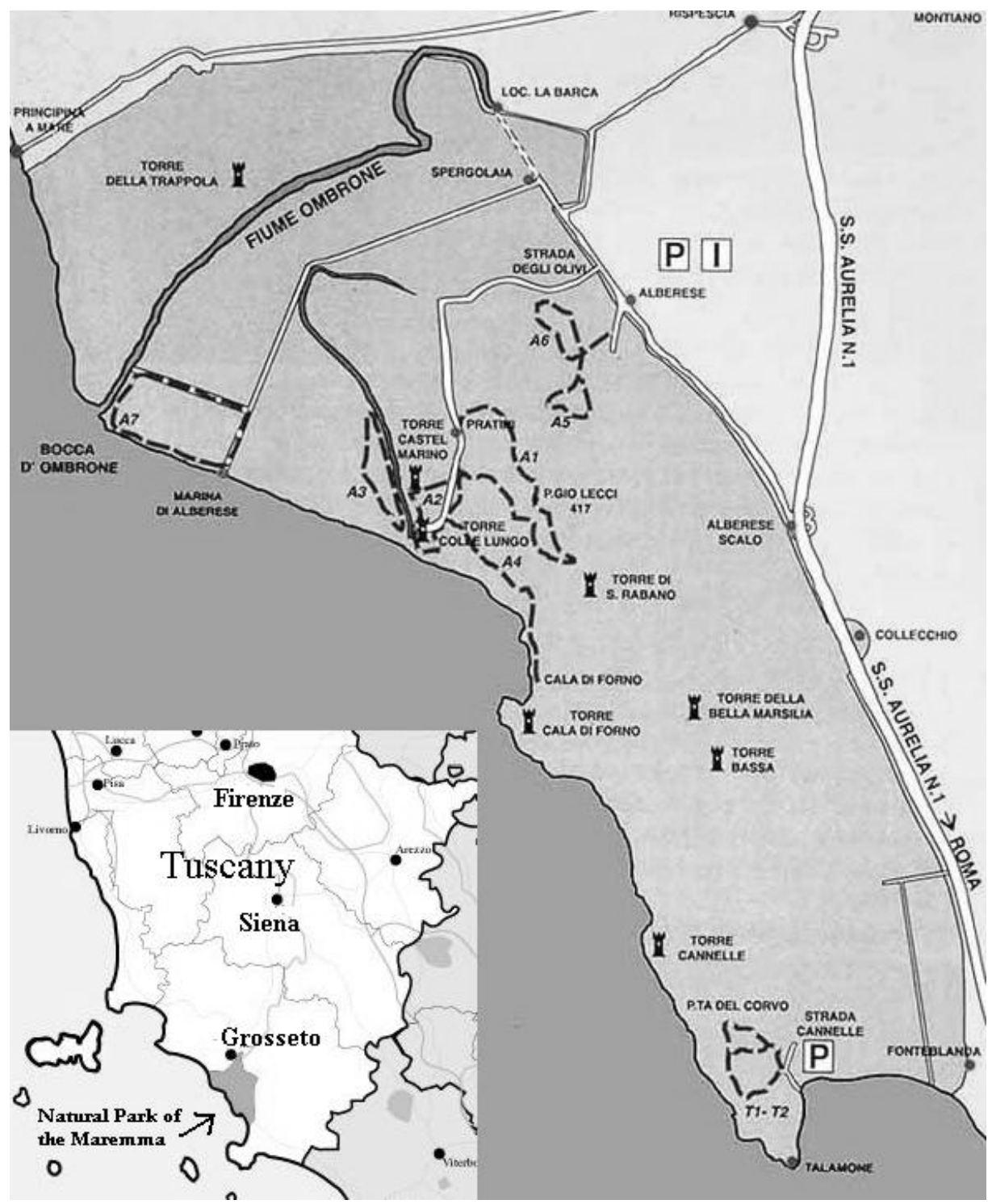

Figure 1 The Park 
Study site

Located on the coast of southern Tuscany, the Maremma is a well-known beach tourism destination. Under the pressure of real-estate development, especially along coast, in 1975 part of this region was set aside as a Regional Park in order to protect the outstanding examples of natural interest and beauty. It is the first park in Tuscany and one of the oldest in Italy. The Natural Park of the Maremma is centrally located and is an important destination for NBTs. In the last decade paying visitors have increased from about 49,000 to 80,000 a year. Park visitors are more than $20 \%$ of all tourist arrivals in Maremma. This figure rises to $40 \%$ in October, $50 \%$ in May and $60 \%$ in April. These characteristics and the simultaneous presence of NBTs and BTs made the Maremma a suitable area for analyzing the issue at stake.

\section{Data collection and analysis}

The survey took place in summer, during the peak tourist season for the park and neighboring coastal area. Data was collected by means of a questionnaire. Interviews were carried out in two locations, each specific to the type of tourist investigated. A total of 300 interviews were conducted by trilingual interviewers following a systematic sampling procedure ${ }^{8}$. One-hundred and fifty NBTs were selected and interviewed at the park gate, whereas 100 BTs were selected randomly in different types of accommodation. In order to consider day-trippers and owners of second homes, 50 interviews were also conducted with people in these categories on the beach.

For BTs, a set of accommodation facilities was drawn from the list of those available in the area, split into three main geographical sub-areas: Principina a Mare, Castiglione della Pescaia e Talamone/Fonteblanda. Accommodations were stratified into: hotels and the like (RTA, serviced apartments) and campsite and tourist villages. The first stratum was divided according to class: 1 or 2 stars and 3 or 4 stars. There are no 5 star hotels in the area. The sample composition is reported in Table 1.

Table 1 Number of accommodation facilities selected and number of tourists interviewed per geographical area and type of accommodation (in brackets)

\begin{tabular}{|l|c|c|c|}
\cline { 2 - 4 } \multicolumn{1}{c|}{ Type } & \multicolumn{3}{c|}{ Geographical areas } \\
& $\begin{array}{c}\text { Principina a Mare } \\
\text { Marina di Grosseto }\end{array}$ & $\begin{array}{c}\text { Castiglione della } \\
\text { Pescaia Punta Ala }\end{array}$ & $\begin{array}{c}\text { Talamone } \\
\text { Fonteblanda }\end{array}$ \\
\hline Hotel and RTA (1-2 stars) & $1(3)$ & $1(3)$ & $1(3)$ \\
\hline Hotel and RTA (3-4 stars) & $2(9)$ & $6(25)$ & $2(7)$ \\
\hline $\begin{array}{l}\text { Campsites, Residences, } \\
\text { Tourist Villages }\end{array}$ & $3(21)$ & $5(25)$ & $2(4)$ \\
\hline
\end{tabular}


Direct interviews combined with a pre-test produced a high return rate (about 95\%), with no substantial differences between the two sub-samples. Both types of tourist were asked to answer the same questions. Since several types of NBT overlap with other types of tourist, BTs were asked a filter question to exclude individuals who had visited the park.

Due to the hypothesis put forward in the paper (i.e. that the proportion of individuals with certain characteristics is higher among the NBTs than among the BTs) and the characteristics of the sample, no assumption was made on the probability distribution of the variables, and a permutation technique, or the Fisher exact test, was used to analyze the data (non-parametric method). In fact, this independence test can be used regardless of the sample characteristics.

\section{Results}

Considering previous international research results (Epler Wood 2002; Wight 1996a; Boo 1990) and the lack of an unanimously shared operational framework (Priskin, 2003; Smith and Eadington, 1995), and considering the characteristics that are generally assumed to identify different types of tourist, the survey focused on selected descriptive (socio-demographic) characteristics together with intention (willingness) and outcome (actions) variables, looking for stylized facts supporting the hypothesis put forward in the definition of alternative tourist. Because of the nature of the study and the lack of unanimously accepted quantitative indices, tourists were compared in terms of the intensity of selected features rather than in terms of selected indicators ${ }^{9}$.

Statistical analysis confirmed that NBTs were older, more educated, more affluent, and more often employed/engaged in professional occupations. No specific findings emerged regarding length of stay or travel organizations. Trip was mainly selforganized. The main results are shown in Table 2. Table 3 reports the summary of independence test and their statistical significance.

The results also confirmed that park visitors were more sensitive to environmental issues. Tourists were asked to place some relevant social problems in order of importance. The majority (74\%) of NBTs indicated pollution as their major concern, whereas this was true for less than 1/3 of BTs (29\%), the latter being more worried about crime and unemployment. However, a high percentage of both types of tourist (100\% and $84 \%)$ considered that environmental quality had a positive effect on individual welfare. Consistently, we expected that environmental quality influenced consumer choices and the prices consumers were willing to pay for certain type of goods. 
Table 2 Main socioeconomic and behavioural characteristics

\begin{tabular}{|l|c|c|}
\hline Characteristics & Park visitors & Beach tourists \\
\hline Median age & 43 & 39 \\
\hline Sex & 52\% male; 48\% female & 57\% male; 43\% female \\
\hline Education (median class) & Degree & High school diploma \\
\hline Income (median class) & EUR 42,000-54,000 & EUR 6,000-18,000 \\
\hline Occupation & More professional & Less professional \\
\hline Nationality & $\begin{array}{c}\text { Italians 53\% } \\
\text { Foreigners 46\% }\end{array}$ & $\begin{array}{c}\text { Italians 76\% } \\
\text { Foreigners 24\% }\end{array}$ \\
\hline Home provinces of Italians & $\begin{array}{c}\text { Tuscany or neighbouring } \\
\text { regions 34\% }\end{array}$ & $\begin{array}{c}\text { Tuscany or neighbouring } \\
\text { regions 78\% }\end{array}$ \\
\hline Micro-facilities run by local family: & Farm-stay 30\% & Farm-stay 2\% \\
\hline Accommodation & Typical restaurants 93\% & Typical restaurants 54\% \\
\hline Food & EUR 42-55 & EUR 18-30 \\
\hline $\begin{array}{l}\text { Average daily expenditure } \\
\text { (median class)* }\end{array}$ &
\end{tabular}

Note: * Excluding the travel costs and overnight stay

Table 3 Park visitors vs Beach tourists: summary of independence test

\begin{tabular}{|l|c|c|c|}
\hline Characteristics & $d f$ & $\chi 2$ & p-value \\
\hline Pollution, unemployment and crime & 2 & 23.6510 & $<.0001$ \\
\hline Preference to reside in unpolluted area rather than city & 1 & 20.0970 & $<.0001$ \\
\hline Environmental quality and perceived welfare & 2 & 17.2106 & $<.0001$ \\
\hline Interest in home purchase in park area & 1 & 67.6933 & $<.0001$ \\
\hline WTP higher price for home in park area & 2 & 2.3016 & .3299 \\
\hline Preference for local and organic products & 1 & 44.5829 & $<.0001$ \\
\hline $\begin{array}{l}\text { Importance ascribed to availability of organic and local } \\
\text { products in hotel }\end{array}$ & 1 & 26.8122 & $<.0001$ \\
\hline Effect of environmental quality mark on choice of hotel & 1 & 13.8971 & $<.0001$ \\
\hline WTP higher price for certified products & 2 & 24.5806 & $<.0001$ \\
\hline
\end{tabular}

Note: * The independence test was carried out using the usual permutation techniques or the Fisher exact test.

Software: SAS 
In order to verify this issue, tourists were asked whether they would be interested in purchasing a house in a natural park. ${ }^{10}$ Park visitors were more favorably disposed to the idea of house purchase than were BTs (85\%vs. 31\%), having the possibility to do so and knowing the restrictions connected with such ownership. Other things being equal, a high percentage of those interested in purchasing a house in a park were willing to pay a higher price for it $(66 \% v s \text {. } 58 \%)^{11}$. This confirms that environmental quality is a source of welfare for these tourists. In fact, according to the theory of consumer choice, people are expected to choose the alternative that generates the highest utility.

In order to investigate whether NBTs are more ecologically oriented than BTs, respondents were also asked about their attitude to local produce. NBTs showed greater interest in local products, such as those labeled PDO (Protected Designation of Origin), PGI (Protected Geographical Indication), TSG (Traditional Specialty Guaranteed) and organic, than BTs. The former declared that marks certifying local, environment-friendly or organic produce would influence their choice and stimulate their expenditure. They would be willing to pay higher prices for such products and services.

When respondents indicate their choices in hypothetical scenarios, it is important to test whether stated choices are in line with actual choices. In our survey factual evidence of actual spending patterns of respondents was consistent with the importance they declared to ascribe to quality marks. Park visitors devoted a higher percentage of their daily expenditure to the purchase of local and environment-friendly products that cost more than generic products. Although this was confined to tourists with higher daily expenditure ( $>55$ EUR), the test highlighted that expenditure for typical products was related to tourist type ( $p$-value $<.002)$. This implies that park visitors generate a stronger demand for local products in absolute terms.

The demand for local products gives rise to more equitable economic growth, due to the widespread network of small and medium enterprises that produce them and to their greater multiplier effect. Since the economic multiplier is negatively related to propensity to import, demand for locally produced goods has a more positive economic impact on an area. By sustaining typical products, one also preserves landscape and cultural traditions.

Three main innovative findings are worth noting. The survey revealed a strong relationship ( $p$-value < .0001) between the variables "income" and "visit to the park". Although conceptually and practically different, this result is consistent with a much debated hypothesis in environmental economics, the Income Elasticity Hypothesis. According (IEH) to this hypothesis, the demand for nature increases more than proportionally with income, making the environment, in the broadest sense, a luxury good. $^{12}$ 
Similarly, a strong relationship ( $p$-value $<.0001)$ was found between level of education and visitors to the park: for a given income, park visitors had a higher level of education. Again, although conceptually different and aware of the improper use of the concept, education being in se a discrete variable, we are inclined to take this piece of evidence as a sort of Education Elasticity Hypothesis (EEH).

Finally, for BTs, the results confirmed that the sympathy for certain goals does not translate into acceptance of costs and sacrifices that actual application may entail (Butler 1998). This is not so for park visitors who were less willing to delegate and more favorably disposed to personal commitment. BTs were interested in environmental issues but baulked at direct commitment. In more rigorous economic language, externalities were potentially-relevant but not Pareto-relevant for BTs (Buchanan and Stubblebine 1962). ${ }^{13}$

\section{Conclusion}

Despite the limits of the data collecting and sampling procedure of the present study, the research contributes in filling the gap that exists in the literature on the NBT and provides new data on this phenomenon. The findings of this study have significant theoretical and practical implications. The first relates to the socio-demographic profile and attitudes of NBTs. The research confirms the findings of others studies (Mehmetoglu, 2007; Wurzinger and Johansson, 2006; Priskin 2003; Epler Wood 2002; Hvenegaard and Dearden 1998; Meric and Hunt, 1998; Silverberg et al., 1996), i.e. that NBTs are older, more educated, more affluent, and engaged in more professional occupations than other types of tourist, in our case frequenters of beach resorts. The results are also consistent with the principles that define the NBTs (Wurzinger and Johansson, 2006; Macleod, 2003; Jafari, 2000; Blamey and Braithwaite, 1997; Wight, 1996b; Cazes, 1989). In fact, the research demonstrates that they are more environmentally aware, more interested in local and "green" products, prefer small and family run rather than large-scale accommodation, and engender a greater multiplier effect. Considering the Plog's work on the allocentric-psychocentric continuum (Plog, 1974), this also confirms the supposed allocentric tendencies of the NBTs (Weaver, 1999).

Statistical analysis showed that these aspects depend more on tourist type than socio-demographic and economic characteristics. This has an interesting theoretical implication, because it highlights the strong role played by psychographic information in understanding tourist behavior. This is an important aspect to consider when designing policies for the management and marketing of nature-based tourism destinations.

The study also highlights some innovative aspects. Data analysis showed a strong relationship between income, education and demand for nature. As stated, this is consistent with the IEH and EEH (see Bimonte, 2002 and Magnani, 2000). It also 
proved that NBTs have a greater multiplier effect and this is true irrespective of daily expenditure. Previous studies have generally been restricted to analyzing willingness to pay and average daily expenditure of different categories of tourists. However, a given daily expenditure can have very different impacts on the local environment and socioeconomic systems, as should already be quite clear. This and the interaction of tourism with other economic sectors is in need of further research.

As a concluding remark, it is worth stressing a final point. As indicated by Mehmetoglu (2007), not all tourists visiting nature-based resources can be considered NBTs from a motivational perspective. However, motivation cannot be the only criterion for defining NBTs. Although a distinction between forms of tourism is feasible, it is much more difficult to discriminate between types of tourist, since tourists normally engage in a variety of activities during a vacation. Weaver (2001) maintains that many if not most soft ecotourism participants are mass tourists engaged in such activities as part of a broader itinerary. This is exactly the case of this research. Nevertheless, the results demonstrate that tourists engaged in nature-oriented activities (park visitors) had completely different behavior and attitudes from those who did not (BTs), irrespective of type of holiday.

These findings should not be overlooked. They suggest that the resources upon which nature-based tourist flows are based can contribute positively to local development, if managed carefully. This and the incidence and even distribution of NBT flows should not be underestimated, because it is a useful support for tourist policies that aim at de-seasonalzing tourist activity, spurring expenditure and sustaining the local economy, rather than merely increasing tourist numbers.

To conclude, although the survey confirms that alternative tourism has the potential to promote positive local economic, social and environmental effects, it would be wrong to consider alternative tourism as a panacea (Butler 1990; Brockelman and Dearden 1990; Butler, 1990; Cohen, 1987) as it could be as damaging as mass tourism if not managed properly. Because of this, and considering the size of naturebased tourist flows, it would be a shrewd political bet for local planners to modify the attitude and behavior patterns of all types of tourists in order to make them conform to the principles defining alternative tourists. To this end, a modification of the characteristics of the supply side and instruments of a non-technical ${ }^{14}$ nature are required.

\section{Acknowledgement}

This work is part of the research project "Protection, fruition and local development: protected areas and tourism in Tuscany" financed by the Region of Tuscany and carried out together with IRPET (Regional Institute for Economic Planning of Tuscany). The author gratefully acknowledges them. A special thank goes 
also to the staff of Natural Park of Maremma. The author is also in debt with Caterina Pisani for her helpful comments and for having looked after the data processing.

\section{Endnotes}

${ }^{1}$ For a deeper analysis of this aspect see Cater (1993), Wearing and Neil (1999), Jafari (2000), and Newsome et al. (2002). According to the study carried out by Sirakaya et al. (1999), this is also the view shared by the eco-tour operators.

${ }^{2}$ Although conceptually different, the terms nature-based tourism and ecotourism have been used interchangeably in the tourism literature. However, it is generally accepted that ecotourism is a form of nature-based tourism. Ecotourism is normally considered to be a sustainable version of nature tourism (Epler Wood, 2002; Hall and Boyd, 2005). The definitional issue is beyond the scope of the present paper: readers are referred to the abundant literature on the topic (see Jafari, 2000; Newsome et al., 2002; Mehmetoglu, 2000; Wight, 2001; Meric, and Hunt, 1998; IUCN, 1993; Whelan, 1991; Farrell and Runyan, 1991). A review of the existing literature on ecotourism definitions may be foud in Sirakaya et al. (1999). They also

${ }^{3}$ A rough estimate of the international ecotourism arrivals would be 7\% (Lindberg, 1998, quoted in Epler Wood, 2002).

${ }^{4}$ See Hvenegaard, and Dearden (1998) and Silverberg et al. (1996). A review of segmentation studies and approaches may be found in Dolnicar (2004).

${ }^{5}$ Only Wurzinger and Johansson (2006) conducted a similar investigation but by a different method.

6 Therefore, recalling the classification introduced by Weaver (2005), the study used a "minimalist" rather than a "comprehensive" view to approach the problem.

${ }^{7}$ Although simplistic, this is the usual association made (Weaver, 2001).

${ }^{8}$ The systematic sampling procedure is a statistical method requiring the selection of every $\mathrm{k}^{\text {th }}$ element from a population, starting with one randomly selected observation.

${ }^{9}$ The selection of the indicators and their respective weights is a very difficult task, also because these are normally site and time specific. On this aspect see what stated by Weaver (2005).

${ }^{10}$ This is an increasing phenomenon in some regions (Buckley, 2003).

${ }^{11}$ This is consistent with the theory of Lancasterian demand (Lancaster, 1966). It is worth noting that we are in a context of stated preference.

${ }^{12}$ In the case of a luxury good, the curve of Engel, that is the curve that shows the relationship between the demand for a good and the income level, is not linear. All other things being equal, it follows that demand for the good increases more than proportionally with income and, as a consequence, the composition of the basket of purchased goods varies.

${ }^{13}$ An externality is defined as potentially relevant when the activity, to the extent that it is performed, generates any desire on the part of the externally benefited (damaged) party (A) to modify the behaviour of the party empowered to take action (B). An externality which, to the extent that it is performed, exerts no such influence is defined as irrelevant (Buchanan and Stubblebine, 1962, p. 201-202). However, the simple desire to modify the behavior of another party does not necessarily imply the ability to translate this desire into practice. An externality is defined to be Pareto-relevant when the extent of the activity may be modified in such a way that the externally affected party (A) can be made better off without the acting party (B) being made worse off.

14 "A technical solution may be defined as one that requires a change only in the techniques of the natural sciences, demanding little or nothing in the way of change in human values or ideas of morality" (Hardin, 1968, p. 112). See also Bimonte (2008). 


\section{References}

1. Acott, T. G., H. L La Trobe, S. H. Howard (1998) An evaluation of deep ecotourism and shallow ecotourism. Journal of Sustainable Tourism, 6(3), pp. 238253

2. Aylward, B., E. Lutz (eds) (2003) Nature tourism, conservation, and development in KwaZulu-Natal, South Africa. Washington, D.C.: World Bank

3. Baloglu, S., K. W. McCleary (1999) U.S. International pleasure travelers' images of four Mediterranean destinations: A comparison of visitors and non-visitors. Journal of Travel Research, 38(2), pp. 144-152

4. Bimonte, S. (2008) The "tragedy of tourism resources" as the outcome of a strategic game. A new analytical framework. Ecological Economics, forthcoming

5. Bimonte, S. (2002) Information access, income distribution, and the Environmental Kuznets Curve. Ecological Economics, 41(1), pp. 145-156

6. Blamey, R. K., V. A. Braithwaite (1997) A Social value segmentation of the potential ecotourism Market. Journal of Sustainable Tourism, 5 (1), pp. 29-44

7. Bonn, M.A., S. J. Joseph, Mo Dai (2005) International versus domestic visitors: An examination of destination image perceptions. Journal of Travel Research, 43(3), pp. 294-301

8. Boo, E. (1990) Ecotourism: The potentials and pitfalls. Washington, DC: World Wide Fund for Nature

9. Brockelman, W.Y., P. Dearden (1990) The role of nature trekking in conservation: A case-study in Thailand. Environmental Conservation, 17, 141-148

10. Brohman, J. (1996) New directions in tourism for third world development. Annals of Tourism Research, 23(1), pp. 48-70

11. Buchanan, J. M., W. C. Stubblebine (1962) Externalities. Economica 29, pp. 371-384

12. Buckley, R. (2003) The practice and politics of tourism and land management. In R. Buckley, C. Pickering and D. B. Weaver (eds.) Nature-based tourism, environment and land management. Wallingford, UK, Cambridge, USA: CABI Publishing

13. Butler, R. W. (1998) Sustainable tourism looking backwards in order to progress? In C. M. Hall and A. A. Lew (eds.) Sustainable Tourism: A Geographical Perspective. Essex: Longman, pp. 24-34

14. Butler, R.W. (1990) Alternative tourism: Pious hope or Trojan horse? Journal of Travel Research, 28(3), pp. 40-45

15. Cazes, G. H. (1989) Alternative tourism: Reflections on an ambiguous concept. In T. V. Singh, H. L. Thevas, F. M. Go (eds.) Towards appropriate tourism: The case of developing countries. Frankfurt am Main: Peter Lang, pp. 117-126 
16. Ceballos-Lascurain, H. (1988) The future of "ecotourism”. Mexico Journal, January 27, 13-14

17. Clarke, J. (1997) A framework of approaches to sustainable tourism. Journal of Sustainable Tourism, 5(3), pp. 224-233

18. Cohen, E. (1987) Alternative tourism: A critique. Tourism Recreation Research, XII (2), pp. 13-18

19. Dernoi, L. (1981) Alternative tourism: towards a new style in North-South relations. International Journal of Tourism Management, 2, pp. 253-264

20. Dolnicar, S. (2004) Beyond “commonsense segmentation”: a systematics of segmentation approaches in tourism. Journal of Travel Research, 42(3), pp. 244-250

21. Epler Wood, M. (2002) Ecotourism: Principles, practices and policies for sustainability. Paris: UNEP

22. Farrell, B. H., D. Runyan (1991) Ecology and tourism. Annals of Tourism Research, 18(1), pp. 26-40

23. Hall, C. M., S. Boyd (2005) Nature-based tourism in peripheral areas: an introduction. In C. M. Hall, S. Boyd (eds.) Nature-based tourism in peripheral areas: Development or disaster? Clevedon: Channel View Publications, pp. 3-17

24. Hardin, G. (1968) The Tragedy of the Commons. Science, 162, pp. 1243-1248

25. Holden, A., J. Sparrowhawk (2002) Understanding the motivations of ecotourists: The case of trekkers in Annapurna, Nepal. International Journal of Tourism Research, 4(6), pp. 435-446

26. Hvenegaard, G. T. (2002) Using tourist typologies for ecotourism research. Journal of Ecotourism, 1(1), pp. 7-18

27. Hvenegaard, G. T., P. Dearden, (1998) Ecotourism versus tourism in a Thai National Park. Annals of Tourism Research, 25(3), pp. 700-720

28. IES, (2000) Ecotourism statistical fact sheet. Washington, DC: International Ecotourism Society

29. IUCN (1993) Parks for life: Report of the IV World Congress on National Parks and Protected Areas. Gland, Switzerland: IUCN

30. Jafari, J. (ed.) (2000) Encyclopaedia of Tourism. London: Routledge

31. Jafari, J. (1990) Research and scholarship: The basis of tourism education. Journal of Tourism Studies, 1(1), pp. 33-41

32. Kashyap, R., D. C. Bojanic (2000). A structural analysis of value, quality, and price perceptions of business and leisure travelers. Journal of Travel Research, 39 (1): 45-51

33. Lancaster K. (1966) A new approach to consumer theory. Journal of Political Economy, 84(2), pp. 132-157

34. Lang, C. T., J. T. O’Leary (1997) Motivation, participation, and preference: A multi-segmentation approach of the Australian nature travel market. Journal of Travel and Tourism Marketing, 6(3/4), pp. 159-180 
35. Laarman, J. G., P. B. Durst (1987) Nature travel in the tropics. Journal of Forestry, 85(5), 43-46

36. Lindberg, K. (1998) Economic aspects of ecotourism. In K. Lindberg, M. Epler Wood, D. Engeldrum (eds.). Ecotourism: a guide for planners and managers. Volume 2. Burlington, VT, USA: The International Ecotourism Society

37. Lindberg, K. (1991) Policies for maximizing nature tourism's ecological and economic benefits. International conservation financing project working paper, Washington, DC: World Resources Institute, pp. 1-37

38. Lindberg, K., J. Enriquez, K. Sproule (1996) Ecotourism questioned: Case studies from Belize. Annals of Tourism Research, 23(3), pp. 543-562.

39. Lou, Y., J. Deng (2008) The new environmental paradigm and nature-based tourism motivation. Journal of Travel Research, 46(4), pp. 392-402

40. Macleod, D. (2003) Alternative tourism: A comparative analysis of meaning and impact. In W. F. Theobald (ed.) Global Tourism. Oxford: Butterworth-Heinemann, pp. 150-167.

41. Magnani, E. (2000) The Environmental Kuznets Curve, environmental protection policy and income distribution. Ecological Economics, 32(3), pp. 431-443

42. McKercher, B. (2001) A comparison of main destination visitors and through travellers at a dual purpose destination. Journal of Travel Research, 39(4), pp. 433-441

43. Mehmetoglu, M. (2007) Typologising nature-based tourists by activitytheoretical and practical implications. Tourism Management, 28(3), pp. 651-660

44. Mehmetoglu, M. (2005) A case study of nature-based tourists: Specialists versus generalists. Journal of Vacation Marketing, 11(4), pp. 357-369

45. Meric, H. J., J. Hunt (1998) Ecotourists' motivational and demographic characteristics: A case of North Carolina travelers. Journal of Travel Research, 36(4), pp. 57-61

46. Mowforth, M., I. Munt (1998) Tourism and Sustainability: New Tourism in the Third World. Routledge

47. Newsome, D., S. A. Moore, R. K. Dowling (2002) Natural area tourism: Ecology, impacts and management. UK: Channel View publications

48. Nyaupane, G. P., D. B. Morais, A. R. Graefe (2004) Nature-based tourism constraints: A cross-activity comparison. Annals of Tourism Research, 31(3), pp. 540555.

49. Plog, S. C. (1974) Why destination areas rise and fall in popularity. The Cornell Hotel and Restaurant Administration Quarterly, 14(4), pp. 55-58

50. Priskin, J. (2003) Issues and opportunities in planning and managing naturebased tourism in central coast region of Western Australia. Australian Geographical Studies, 41(3), pp. 270-286 
51. Silverberg, K. E., S. J. Backman, K. F. Backman (1996) A preliminary investigation into the psychographics of nature-based travelers to the southeastern United States. Journal of Travel Research, 35(1), pp. 19-28

52. Sirakaya, E., V. Sasidharan, S. Sönmez, (1999) Redefining ecotourism: the need for a supply-side view. Journal of Travel Research, 38(2), pp. 168-172

53. Smith, V. L., W. R. Eadington (1995) Introduction: the emergence of alternative forms of tourism. In V. L. Smith, W. R. Eadington (eds.) Tourism alternatives. Potentials and problems in the development of tourism. Chichester: John Wiley \& Sons

54. Taylor, J. E., G. A. Dyer, M. Stewart, A. Yunez-Naude, S. Ardila (2003) The economics of ecotourism: A Galápagos islands economy-wide perspective. Economic Development and Cultural Change, 51(4), pp. 977-997

55. Wallace, G. N., S. M. Pierce (1996) An evaluation of ecotourism in Amazons, Brazil. Annals of Tourism Research, 23(4), pp. 843-873

56. Wearing, S., J. Neil (1999) Ecotourism: Impacts, Potentials and Possibilities. Oxford: Butterworth-Heinemann

57. Weaver, D. B. (2005) Comprehensive and minimalist dimensions of ecotourism. Annals of Tourism Research, 32(2), pp. 439-455

58. Weaver, D. B. (2002) Hard-core ecotourists in Lamington National Park, Australia. Journal of Ecotourism, 1(1), pp. 19-35

59. Weaver, D. B. (2001) Ecotourism in the context of other tourism types. In D. B. Weaver (ed.) The encyclopaedia of ecotourism. New York: CABI

60. Weaver, D. B. (1999) Magnitude of ecotourism in Costa Rica and Kenya. Annals of Tourism Research, 26(4), pp. 792-816

61. Weaver, D. B., B. Faulkner, L. Lawton (1998) Nature-based tourism in Australia and beyond: A preliminary investigation. Gold Coast, Queensland: Cooperative Research Centre for Sustainable Tourism, Griffith University.

62. Whelan, T. (1991) Nature tourism: Managing for the environment. Washington, USA: Island Press

63. Wight, P. A. (2001) Ecotourists: Not a homogeneous market segment. In D. B. Weaver (ed.), The encyclopaedia of ecotourism. New York: CABI, pp. 37-62

64. Wight, P. A. (1996a) North American ecotourists: Market profile and trip characteristics. Journal of Travel Research, 34(4), pp. 2-10

65. Wight, P. A. (1996b) North American ecotourists: Motivations, preferences and destinations. Journal of Travel Research, 35(1), pp. 3-10

66. Wight, P. A. (1993) Sustainable ecotourism: Balancing economic, environmental and social goals within an ethical framework. Journal of Tourism Studies, 4(2), pp. 54-66 
67. Wurzinger, S., M. Johansson (2006) Environmental concern and knowledge of Ecotourism among three groups of Swedish tourists. Journal of Travel Research, 45(2), 217-26

68. Xiao, H., S. L. J. Smith (2006) Case studies in tourism research: A state-of-theart analysis. Tourism Management, 27(5), pp. 738-749

RECEIVED: 31.10.2007

ACCEPTED: 01.10.2008 